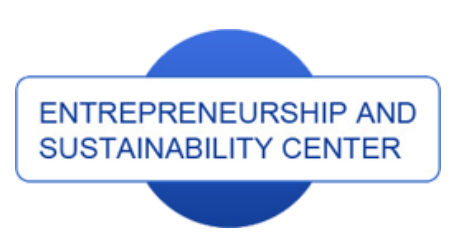

Publisher

http://jssidoi.org/esc/home
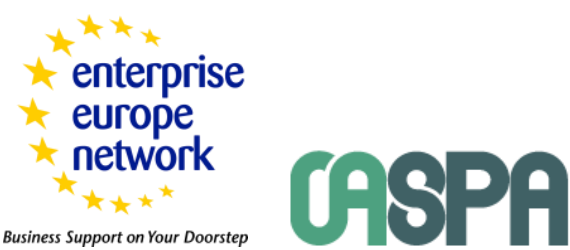

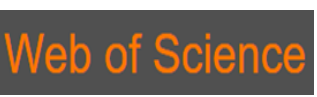

\title{
PUBLIC ADMINISTRATION FOR SAFE AND SECURE ENVIRONMENT: CASE OF SLOVAK REPUBLIC
}

\author{
Jozef Kuril \\ School of Economics and Management Public Administration, Bratislava, \\ Furdekova 16, 85104 Bratislava, Slovenská Republika \\ E-mail:jozef.kuril@vsemvs.sk
}

Received 15 November 2017; accepted 13 February 2018; published 30 March 2018

\begin{abstract}
Important roles of the public administration in the Slovak Republic also include the formation and reinforcement of the state security system. The notion of civil service is not uniformly understood in legal theory. The Institute has a complex character, which includes a wide range of theoretical and practical questions. We understand the state service as the activity of civil servants. Those acting for a state are members of civil service. The state service may also designate the legal regime of the employees of the state apparatus, or the civil service may represent people as well as the activities of persons operating in the state apparatus. State employee is a person in a legal relationship with the state. The specific form of state service is depending on a number of factors in a number of countries. The embedding of state service in the constitutions of European states has several content ranges. Public administration impacts safety and security of a country, and therefore is considered as precondition of sustainable entrepreneurship and sustainable economic development of any country.
\end{abstract}

Keywords: public administration, state administration, public service, civil service, state security, legal environment, precondition of sustainable entrepreneurship, precondition of sustainable economic development

Reference to this paper should be made as follows: Kuril, J. 2018. Public administration for safe and secure environment: case of Slovak Republic, Entrepreneurship and Sustainability Issues 5(3): 493-501. https://doi.org/10.9770/jesi.2018.5.3(6)

JEL Classification: K31, H12, H56, K14

Additional disciplines: law 


\section{Introduction: public administration and state security}

In this article, we apply a systemic approach to the addressed issue, mainly by using a method involving analysis and synthesis as general methods of scientific discovery. From other methods of scientific research, we apply logical methods of deduction and induction accordingly, as well as methods of comparison, observation, and abstract examination. The use of these methods leads to a deeper understanding of the particular issue. It also makes it possible to get to its core, as well as in relation to other subjects or phenomena.

Important roles of the public administration in the Slovak Republic also include the formation and reinforcement of the state security system, which is important precondition of development of sustainable entrepreneurship and sustainable economic development of country in current turbulent and insecure world (Beinoravičius, Vainiute 2017; Danišauskas 2017; Zeman et al. 2017; Tumalavičius, Šakočius, 2017; Kuril 2018).

Public administration in a systemic and differentiated way contributes to the protection of the external and internal security of the state, and it participates to a great extent in the protection of state order and implements and ensures important tasks and measures related to crisis management. Public administration is also legitimately considered an individual and special service for the public. The public administration sector without a doubt includes law enforcement activities, namely various types of police services carried out by officers of the Slovak Police for the benefit of society (Siller, Cibák 2016, Kabát et al. 2016).

\section{The concept and content of the civil service}

Service in the sense of a certain obligation towards to whom it is being provided (the public, the state), in combination with this description (the public, the state) forms the terms public service and state service. Public service is activity carried out in public administration in all of its parts, meaning in state administration, local government and in public legal corporations. Public service can also be understood as a group of persons carrying out service for the benefit of a public legal corporation. In comparison to what has been referred to above, state service is a narrower term, because the definition of state service includes "only" activity performed in state administration as well as a group of persons carrying out service "only" for the benefit of a state and in relation to a state.

State service can be classified as follows:

- At its organizational level, meaning as part of an organizational system of a state as part of a state apparatus;

- From the point of view of certain activity: This involves activity of state employees performing state functions;

- As a group of persons: This defines a certain group of persons (state employees) in state services;

- As a legal regime: This expresses a means of arrangements of legal regulation of state employees;

- As a legal relationship: This represents a legal relationship between state employees and the state;

- As a legal institute, in the sense of a set of legal standards regulating a specific homogeneous group of social relationships. (Čebišová 2001)

Even in legal theory the term state service is not understood uniformly, due to the multiple possible perceptions of this term. 
The International Journal

ENTREPRENEURSHIP AND SUSTAINABILITY ISSUES

ISSN 2345-0282 (online) http://jssidoi.org/jesi/

2018 Volume 5 Number 3 (March)

http://doi.org/10.9770/jesi.2018.5.3(6)

State service is focused on mainly by the theory of administrative law, and it emphasizes the complex nature of the particular institute, which includes a wide range of theoretical and practical issues. State service is an inevitable an important part of state organization of society, and its function in society is conditioned on tasks and functions of the state and on their ensuring in which civil servants take part. The state defines the legal regime of state employees so that it can mainly ensure the fulfilment of state (public) interests. However, in the arrangement of state service the interests of employees are reflected more or less as well (Škultéty 2008).

If someone carries out a certain activity for the state based on having been entrusted to do so, it can be easily stated that such person is performing state service. State service can be understood as activity of state employees involving performance of state roles as the activity of employees of the state apparatus performed in a stateservice relationship. As the result of the division of work, the state service creates a subsystem of community work and is part of labour law. However, it is also part of the organizational and legal system of the state apparatus, and therefore it belongs to the system of administrative law. There is no doubt that state service is of the complex nature and has a comprehensive scope. State service problems have many forms and an interdisciplinary character in the sphere of law.

The term state service is usually used in a double sense, first, as a description of activities of the employees of the state apparatus and, second, as a description of the legal regime of such persons. Unlike the general employee regime, state service represents a different and specific legal regime in that it must cover the specificities of this regime by its very nature as service.

In the legal sense, state service can be defined as a set of legal standards which regulate the status of the employees of the state apparatus (state employees). These standards regulate the creation, course and expiration of legal conditions in state service, the rights, duties and responsibilities of civil servants, and this means that they regulate the legal regime for state employees.

In the legal sense, state service represents a complex legal institute, which includes standards of various branches of law (institutional, administrative, labour etc.). The institute of state service is created by legal standards defining, the nature and sense of a numerous set and wide range of state service relationships. Standards regulating state service relationships are interconnected and, in summary, they form the institute of state service. The institute of state service is also formed by the legal standards which regulate: the establishment of a state service relationship, principles of service, rights and duties of a state employee and termination of a state service relationship.

The modern legal institute of state service is a set of legal standards, which regulate relationships formed within the organisation of the state service system, the status of state employees, i.e. legal regulation of the status of state employees in their employment relationships and as a mechanism for fulfilment of tasks in state service. The concept of the legal regulation of state service includes three major areas in the system of state service relationships:

- Formation and organization of the state service system;

- Legal regulation of the status of state employees (their status);

- Mechanism for performance of state service.

Despite their complexity, legal means used in the area of legal regulation of state service have common regulatory bases. All of them operate in a specific environment typical for the legal regime of state service. In this specific legal environment of the state service system, specific means and methods of legal regulation are also applied: permission, prohibition, obligations, subordination, control, trust of the state, loyalty etc. 
The International Journal

ENTREPRENEURSHIP AND SUSTAINABILITY ISSUES

ISSN 2345-0282 (online) http://jssidoi.org/jesi/

2018 Volume 5 Number 3 (March)

http://doi.org/10.9770/jesi.2018.5.3(6)

The system of standards regulating state service distinguishes between substantive law and procedural law standards. The substantive law standards in the institute of state service enshrine essential characteristics (features) of this institute. These include: principles of state service, the concept of a state employee, their rights and duties, legal limitations, deadlines, guarantees and compensation, certifications, disciplinary responsibility, etc. The procedural law standards regulate relationships aimed at fulfilment of obligations (rights and duties) contained in the substantive law provisions. In the institute of state service we can find specific procedural provisions regarding the approach to the matter of hiring someone into an employment relationship in state service, disciplinary proceedings, termination of an employment relationship in state service etc.

State service includes many different controlling, organizational and other types of relationships and links which require legal regulation in the form of various legal forms via state service standards. State service standards have special features of administrative law regulation, and regulate social relationships which exclude legally equality of the parties to such relationships (Kuril 2006, 2018). In legal regulation involving organization and functioning of state service, public law standards dominate, mainly standards of administrative and constitutional law, while a specific method of regulation of the centralization of powers is applied.

State service, as a legal institute, represents a set of legal standards which regulate mutually closely linked relationships within the organisation of state service, as well as relationships that regulate the status of state employees. State service has two aspects, organisational and legal. In this context, state service is characterized as an organizational legal institute which has its own organizational forms and is regulated by legal standards. In this sense (organizational legal), the institute of state service covers standards regulating the organization of state service (this is built on the organization of the state apparatus) and standards regulating the legal regime of state employees. (Kuril, Minčič, 2015).

In our opinion, the term state service should be understood, on one hand, as the organization of state service and, on the other hand, as the legal regime relating to an employee participating in fulfilment of state tasks via state employee relationship (service relationship).

\section{State employee}

The term state service directly corresponds to the term state employee. This term means an individual in the state employment relationship performing civil service in a state office in accordance with applicable laws of the state. State employees carry out activities in the public (state) interest, and within the scope of their powers and authority they are representatives of the state, can present themselves and act on the state's behalf, directly participate in state power, enjoy individual rights and duties, and have some duties that survive the end of the state employment relationship.

State employees as subjects of public law relationships in state service are able to use their power and governance authority, realize specific rights and duties stemming from the authority of the state (the state apparatus) and state employees are representatives of the state and they are in a close relationship with it. State employees are representatives of public law. The unique public law status of civil servants relates to the fact that state employees have unique and special rights and duties and are subject to certain prohibitions and restrictions, but also compensation and preferences.

State employees as a category of employees in service to the state are differentiated from multiple points of view. One of the most important differentiation criteria is the categorization in terms of the authority and nature of the body in which they serve. From this point of view these are: 


\section{The International Journal}

ENTREPRENEURSHIP AND SUSTAINABILITY ISSUES

ISSN 2345-0282 (online) http://jssidoi.org/jesi/

2018 Volume 5 Number 3 (March)

http://doi.org/10.9770/jesi.2018.5.3(6)

- Employees in state and administrative bodies with positions that define their authority to act externally (manage, decide, control), and the law bestows upon them the authority to act on behalf of the state, and to carry out administrative acts in a quality manner and enjoying special authority and protection;

- Employees in state facilities (such as teachers, physicians) whose activity mainly involves performance of services, who however also have certain authority in relation to citizens (such as confirmation of work disability status, certification of exam completion etc.);

- Employees in state and administrative bodies and/or state facilities performing, unlike the previously specified groups, also services without direct legal effects (such as clerks, accountants etc.).

\section{State employment relations}

Fulfilment of tasks in state service is carried out by state employees via state employment relationships. State employment relationships are conceived as public law relationships. The characteristic features in which the public law nature of state employee relationships are apparent stem from the very idea of these relationships as legal circumstances in which state employees perform state services and thereby directly take part in the exercise of state power for the implementation of the state functions. The nature of these relationships must also correspond to the specificity of the fulfilment of these tasks, and the public law nature of state employment relationships is in direct correlation with the nature of fulfilment of tasks performed which are the subjects of legal relationships.

State employment relationships are formed usually based on a decision - individual legal act. The issuance of a decision assumes that there is prior approval of a particular applicant seeking a state service position or at least a subsequent expression of consent of the employee for being hired into state service even by implicit action. In state employment relationships the state acts as an employer. The state in the position of an employer in these relationships is especially advantageous, because in them it has more leeway as an employer in dealings with the employer as well as a stricter disciplinary regime. This is the case, for example, in the service relationship of police officers. In state employment relationships, an increased level of stability of these relationships is applied, in connection with permanency. The permanency acts as significant stabilization factor in state service; however, but they do not apply to termination of an employment relationship due to a breach of service discipline. The mandatory nature of legal regulations is dominant in state employment relationships. The rights and duties of state employees are laid down by normative provisions and cannot usually be the subject to contractual negotiations. In state employment relationships, certain limitations are applied (such as a ban on business activity and/or other gainful activity), and the state makes up for these restrictions with a legally guaranteed pay and service approach (police officers in state service are entitled to promotion after fulfilling qualification requirements of general and special education and fulfilment of yearly targets in rank). Legal regulation of state service in state employment relationships has a separate position and is regulated by special legislation. Such legislation is independent of general regulation of employment relationships arising on the labour market. In state employment relationships there is a special way of resolving disputes. Whenever a dispute arises regarding the contents and scope of rights and duties, an attempt will first be made to resolve the dispute by a competent service body, and only after that fails the decision taken by the service body can be examined by a court. In state employment relationships, disciplinary responsibility is applied in case of a breach of service discipline. A breach of service discipline establishes disciplinary responsibility with the option of using disciplinary measures against the employee who has breached service discipline.

In view of the above, it can be stated that state service is one of the most important legal institute of the legal system in the Slovak Republic, which includes a wide range of theoretical and practical issues. State service consists of a certain system of social relationships, and an important part of them by its very nature, purpose and 
arrangement is firmly enshrined in the organization of the state apparatus, the most extensive part of which is the organization of state administration.

State service is inevitable and important part of state organization of society, and its function in society is determined by tasks and functions of the state and on their ensuring in which employees of state service take part. State service is a historical, social and legal phenomenon and has strong political and power aspects.

In a democratic state, including our legal system, state service is usually built based on the principles of professionalism, political independence, effectiveness, flexibility, impartiality and ethics and is based on democratic values both in its internal arrangement and in all of its activities. The status of state service is a reflection of society and is one of the indicators of the political situation in a country.

State service has a complex multifaceted character, and state service has an interdisciplinary nature. The institute of state service includes an entire complex of social relationships which are regulated by the standards of more (several) branches of law. The legal regulation of state service includes standards of institutional, administrative and labour law, and therefore, this legal institute cannot be classified clearly and without any doubts only into one traditional branch of law in the legal system in the Slovak Republic (Kuril 2006, 2018).

\section{Constitutional law foundations of state service}

In general, it can be stated that constitutional law enshrinement of the institute of state service in the constitutions of individual countries is a sign not only of public law relationships related to the performance of state service, but it also strengthens the prestige of state service as a whole.

State (public) service and the status of state (public) employee in constitutional law has three levels:

- The first includes the constitutions of countries which are mentioned with regard to individual aspects of state service in relation to equal access to public authorities, the authorization to appoint civil servants without public service itself being the subject-matter of a separate legislative provision.

This group also includes Slovakia, whose Constitution in Article 30 (1) (4) states: "Citizens have the right to participate in the administration of public affairs directly or through election of their representatives," and "citizens have access, under equal conditions, to elected and other public functions." In the case of Article 30 (1) of the Slovak Constitution, this is one of the fundamental political rights of citizens in a democratic society. Under the term "administration of public affairs" it is necessary to understand participation of a citizen in the political life in the state, administration of the state and administration of public matters in municipalities. The right of the citizens to participate in administration of public affairs either directly or through free election of their representatives is understood as a right involving the use of tools of direct or representative democracy. The direct participation of a citizen in the governance of public affairs involves mainly the right of the citizen to participate and vote in a referendum. The participation of a citizen in the governance of public affairs through elected representatives involves the right of the citizen to participate in elections to elect representatives at the local or nationwide level and the right to vote for the candidate of choice for a particular office. The term public affairs need to be understood as including matters of public interest on the governance of which the citizens can participate in accordance with the Constitution of the Slovak Republic in the manners described therein. The exercise of the constitutional right of citizens to participate directly in the governance of public affairs is enabled by the organization and legal arrangement of local governments which create preconditions enabling all inhabitants to participate in the governance of and directly decide about public matters of local importance based on a direct and specific expression of will. This right is guaranteed to all citizens of the Slovak Republic. 
Pursuant to Article 30 (4) of the Constitution of the Slovak Republic, the right to access to elected and other public offices are recognized under equal conditions for each citizen. The provisions of Article 30 (4) of the Constitution of the Slovak Republic guarantee every citizen of the Slovak Republic the right under equal conditions to access to elect and other public offices. However, this does not guarantee the right to hold a public office, only the right to access it. This means the right to run for a public office under conditions equal to those of other candidates. It can be deduced from the respective article of the Slovak Constitution that there is a right to hold a public office if the citizen fulfils all of the legally defined conditions for access to public office. This article of the Slovak Constitution does not guarantee protection from loss of public office prior to the end of the term of office. The above article of the Slovak Constitution recognizes protection of access to elected positions equal to that of other public offices.

We are of the opinion that the status of a public employee should have a place in the provisions of the Slovak Constitution. Institutional enshrinement of state service in the Slovak Constitution would not only correspond to social reality but would also raise the prestige of state service as a whole. A similar legal definition can be found in the constitutions of Belgium, Austria, Luxembourg, and Russia. (Klokočka, Wagnerová 1997)

- The second level consists of constitutions which present state (public) service with a reference that more detailed regulation is set by law.

These constitutions formulate, to a certain extent, both certain formal and substantial principles of state (public) service. This group includes, for example, also the Czech Republic. Article 79 (2) of the Constitution of the Czech Republic states: "The legal situations of state employees in ministries and other administrative bodies are regulated by law." (Klokočka, Wagnerová 1997)

This second level of constitutional expression of state (public) service is among the most represented in the constitutions of the EU Member States. This level is presented by the constitutions of Germany, Denmark, Spain, France, Italy, and the Netherlands. (Kresák 2007)

- The representative of the third level of constitutional law expression of state (public) service and the status of a state employee is mainly Greece. Mainly Greece, but also Portugal and Finland, have constitutions that present multifield and relatively detailed regulation relating to state (public) service.

The Constitution of the Republic of Greece of 9 June 1986 assigns great importance to the issues of public service, holding public offices and status of administrative officer. In addition to the provisions of Article 4 (4), Article 12 (4), Article 16 (6) and Article 29 (3) ("Judges, members of the armed forces and security units and state employees are prohibited from expressing any views in favour of political parties, and employees of public law corporations and local governments are prohibited from acting actively for the benefit of any political party".) The attention devoted to the positions of public administrative officers in all three institutions is above-standard, but the Greek Constitution emphasises the position of "office" and the "position of administrative officials".

The Constitution of the Republic of Portugal of 2 April 1976 does not have a systematically reserved section devoted to public (state) service or its employees; however, the overall scope of the provisions devoted to these issues may also be considered above-standard. Similar statements however even closer to the characteristics of constitutional enshrinement of civil servants in the Constitution of the Republic of Greece, applies in relation to the provisions of the Finnish Constitution. 
The International Journal

ENTREPRENEURSHIP AND SUSTAINABILITY ISSUES

ISSN 2345-0282 (online) http://jssidoi.org/jesi/

2018 Volume 5 Number 3 (March)

http://doi.org/10.9770/jesi.2018.5.3(6)

In addition to the provisions of both constitutions, which refer to the right to access public service based on a tender and the need for legal regulation in the form of a law for civil servants; and state employees (Article 47 (2) and Article 244 (2) of the Portuguese Constitution, Article 91 of the Finnish Constitution), in both constitutions and systematically especially in the Finnish Constitution (though not under the term "status of administrative officials), there are also provisions which can be found, in most legal systems regulating state service, in legal regulations regulating state (public) service, mainly in laws.

\section{Conclusion}

State service is a complex and complicated legal institute, which includes a wide range of theoretical and practical issues. In legal theory, the term "state service" is not understood in a coherent way. State service can be understood in an organisational sense, i.e. as an organisational unit of state service, but also as activity of state employees or the legal regime of state employees or a group of persons acting in state service. The term state service directly corresponds to the term state employee. A state employee is an individual in a legal relationship with a state. State service in the Slovak Republic is performed in state employment relationships, which can have the form of a state employment relationship (state employees during performance of state administration in a state employment relationship with the state and/or a service relationship (members of the Police Forces in a service relationship with the state).

The meaning of constitutional law, as a branch of law, is very important for the legal regulation of state (public) service in the most EU Member States. In many constitutions, the principles of holding public office are enshrined either directly (Greece, Finland), or indirectly (Article 33 (5) of the German Constitution, but also Article 34 of the French Constitution). Service law in relation to public employees is in the most constitutions reduced mainly to employment in a public law service relationship, i.e. as civil servants. Only in certain constitutions which we have mentioned above, attention is paid to employment in the public (state) service based on a private law contract, and the term "civil servant" is not used, but rather such persons are referred to as "employees of public administration (public service", which includes the possibility of employment also on a private law basis.

It can be deduced from the given comparison of constitutional enshrinement of the institute of state (public) service in constitutions how much importance certain EU Member States or most of them assign to the constitutional regulation of state service for proper functioning of a state with the rule of law. Although in general a direct relationship between the constitutional regulation of state (public) service and its actual functioning cannot be expressed only based on legislation without more detailed constitutional arrangements, let us assume that the status of a civil servant (public employee) should also have a certain place in the provisions of the Slovak Constitution. This is also supported by the fact that the terms civil servant and civil servant status tend to be, in the eyes of the public, rather derogatory than perceived as a symbol of the rule of law, impartiality and professionalism in connection with citizens' demands. (Kuril 2006). Legal framework of public administration directly affects efficiency of public employees to maintain safe and secure environment, which in its turn impacts conditions of sustainable entrepreneurship and sustainable economic development. 


\section{References}

Beinoravičius, D.; Vainiutè, M. 2017. The management of terrorism roots as a prerequisite for successful fight against terrorism, Journal of Security and Sustainability Issues 7(2): 193-202. https://doi.org/10.9770/jssi.2017.7.2(2)

Danišauskas, G. 2017. Towards safety of society: rethinking principles of police financing, Journal of Security and Sustainability Issues 7(2): 203-210. https://doi.org/10.9770/jssi.2017.7.2(3)

Kabát, L.; Filip, S.; Filipová, L. 2016 Safety measurement peculiarities in selected countries, Journal of security and sustainability issues 6(3): 343-356. http://dx.doi.org/10.9770/jssi.2017.6.3(2)

Klokočka, V.; Wagnerová, E.. 1997. Constitutions of the EU Member States, Prague, Linde.

Kresák, P. 2007. Constitutions and Constitutional Documents of Selected States, Bratislava, VO PFUK, p. 78.

Kuril, J 2018. Protection of the state and society: public administration and public (state) service, Journal of Security and Sustainability Issues 7(3): 409-416 https://doi.org/10.9770/jssi.2018.7.3(3)

Kuril, J.; Minčič, V. 2015. Public Service in the Slovak Republic, Bratislava, VSEMVS 2015, ISBN 978-80-89654-14-7

Kuril. J. 2006. State Service, Bratislava, Academy of Police Forces, ISBN 80-8054-374-7.7.

Siller, H.; Cibák, L. 2016. Korruption und ihre gesamtwirtschaftliche Bedeutung, in Kriminalistike - Osterreich [Corruption and its macroeconomic significance, in Kriminalistike - Austria] 1/2016, ISBN 978-3-783-084-71/2016, ISBN 978-3-783-084-7

Škultéty, P. 2008. Public Administration and Administrative Law, Bratislava, VEDA ISBN 978-80-224-1023-6

Štangová, N.; Víghová, A.; Múčka, M. 2015. Premises for applying of the process mapping in self-government in Slovakia, Journal of Central European Green Innovation 3(4): 91-98 http://ageconsearch.umn.edu/record/229338/files/Stangova\%20et\%20al.pdf

Tumalavičius, V.; Šakočius, A. 2017. Ensuring public security in the field of traffic safety, Journal of Security and Sustainability Issues 7(2): 233-246. https://doi.org/10.9770/jssi.2017.7.2(5)

Zeman, T.; Břeň, J.; Urban, R. 2017. Role of Internet in Lone Wolf Terrorism, Journal of Security and Sustainability Issues 7(2): 185192. https://doi.org/10.9770/jssi.2017.7.2(1)

Jozef KURIL, prof. JUDr. CSc. is the Head of Security Management Department and teacher of the School of Economics and management in Public Administration in Bratislava. His text books, monographs and scientific papers deal with the Human Security, State Security, State Services. As former Rector of the Academy of Police Forces is succesfull leader and manager of many scientific projects.

Register for an ORCID ID:

https://orcid.org/register

Copyright (C) 2018 by author(s) and VsI Entrepreneurship and Sustainability Center

This work is licensed under the Creative Commons Attribution International License (CC BY).

http://creativecommons.org/licenses/by/4.0/

(c) (i) Open Access 